\title{
Processing of Amaranthus hypochondriacus Biomass for Functional Protein Concentrates Development
}

\author{
Jorge Metri-Ojeda ${ }^{1}$, Costas Nikiforidis ${ }^{2}$, Mutkhar Sandoval-Peraza ${ }^{3}$, Luis Chel-Guerrero ${ }^{4} \&$ Diana Baigts \\ Allende ${ }^{1}$ \\ ${ }^{1}$ Departamento de Ingeniería Química, Alimentos y Ambiental, Universidad de las Américas Puebla, Ex \\ Hacienda Sta. Catarina Mártir S/N, San Andrés Cholula, Puebla 72810, Mexico \\ ${ }^{2}$ Department of Biobased Chemistry and Technology, Wageningen University, Wageningen, The Netherlands \\ ${ }^{3}$ Facultad de Medicina de la Universidad Autónoma de Morelos, leñeros esquina con Iztaccíhualt s/n. Colonia \\ volcanes. C.P. 62350, Cuernavaca, Morelos, México \\ ${ }^{4}$ Facultad de Ingeniería Química, Universidad Autónoma de Yucatán Campus de Ciencias Exactas e Ingenierías, \\ Periférico Nte. Km. 33.5, Tablaje Catastral 13615, Col. Chuburná de Hidalgo Inn, 97203 Mérida, Yucatán, \\ México \\ Correspondence: Diana Baigts Allende, Departamento de Ingeniería Química, Alimentos y Ambiental, \\ Universidad de las Américas Puebla, Ex Hacienda Sta. Catarina Mártir S/N, San Andrés Cholula, Puebla 72810, \\ Mexico. Tel: 01-222-229-2000. E-mail: diana.baigts@udlap.mx
}

Received: August 10, 2019

Accepted: August 23, 2019 Online Published: September 12, 2019

doi:10.5539/jfr.v8n5p71

URL: https://doi.org/10.5539/jfr.v8n5p71

\begin{abstract}
Most proteins for human consumption are animal-derivated sources; however, due to its environmental impact (soil erosion, gas emissions, water footprint) and increasing demand, different plant-based sources are necessary. The purpose of this work is to use amaranth crop biomass for protein concentrates production. The effect of processing (extraction and drying) on the structure and some functional properties of biomass protein concentrates are evaluated for food applications. Thermal and acid precipitation was used for extraction of soluble proteins and lyophilization, vacuum convection, and spray-drying methods for protein concentrates production. Protein structure analyses were gel electrophoresis (SDS-PAGE), isoelectric point (zeta potential), spectrometry (FTIR), calorimetry (DSC), and amino acids profile. The functionality was evaluated by solubility (UV-VIS), rheological and emulsifying properties at different $\mathrm{pH}$ values. The most preserved protein structure was the precipitated by acidification and dried by spraying, which showed the highest solubility values (> $90 \%)$, and desired rheological properties. Lyophilization enhanced the emulsifying activity ( $95 \%)$ and stability to gravity $(\sim 63 \%)$ and heat $(\sim 79 \%)$. The essential amino acids content $(49 \%)$ was higher than FAO recommendations for children (36\%), and protein composition was in agreement with the Codex Alimentarius for plant protein consumption. This research approaches the use of highly available biomass from amaranth crop as a sustainable source of proteins. Mostly protein isolation uses expensive technologies, which increases the final product cost. Herein, a simple method was adequate to obtain high nutritional quality, and food functionality protein concentrates for food-related applications.
\end{abstract}

Keywords: amaranth biomass, protein concentrates, food sustainability

\section{Introduction}

Proteins are very appreciated not only for their nutritional value but also because they are food building blocks, e.g., that can serve as emulsifiers, thickeners, and gelling agents. The functionality of proteins is closely related to their molecular structure and can be environmentally stressed by factors such as temperature, ionic strength, and $\mathrm{pH}$ (Phillips \& Whitehead, 1994).

In response to protein access scarcity mainly in low incomes populations, the use of residual biomass as protein alternative for human consumption (Fiorda, Soares, Da Silva, Souto \& Grosmann, 2013) and animal feeding (Ngugi, Oyoo-Okoth, Manyala, Fitzsimmons \& Kimotho, 2017) has been investigated. Additionally, the enormous environmental impact derived from livestock activities has also motivated the study of plant-based protein sources intending to provide a high nutritional value alternative for food applications. During last years, 
several crops such as pseudocereal seeds (quinoa, amaranth), oleaginous seed (sunflower, Salvia hispanica), duckweed, microalgae, and insects (Van der Spiegel, Noordam \& Van der Fels - Klerx, 2013) have been explored as a source of protein.

Particularly, a promising source for its abundance and currently discarded are the green leaves, which contain several soluble proteins, including green and white (Ribulose-1,5-biphosphate carboxylase/oxygenase known as RuBisCO) fractions. These proteins are studied because of their functional properties in food products development and its biological value (Barbeu \& Kinsella, 1998). Different methodologies for obtaining proteins from tobacco leaves, spinach (De Jong, Geerdink, Bussmann \& Hylkema, 2015), sugar beet (Tenorio, Schreuders, Zisopoulos, Boom \& Van der Goot, 2017) and green tea (Shen,Wang, Wang, Wu \& Chen, 2008) are already reported. However, most of them use specialized and expensive protein purification techniques that could increase the cost of the final product, being no longer affordable for most population (low-income groups).

Autochthonous from the Americas, amaranth is one of the most ancient crops in the world. During pre-Columbian times, this plant was an essential food source for the Aztecs, due to its high protein content, which is higher than in basic cereals such as maize or rice. High cultivation yield, resistance to drought, and nutritional value are the main reasons for its expansion. Nowadays, amaranth is cultivated in India, Africa, Europe, and North America, with the U.S and China being the leading producers (Rastogi \& Shukla, 2013).

Amaranth protein seeds are previously studied as an important source of bioactive compounds (Montoya Rodríguez, Gómez - Favela, Reyes - Moreno, Milán - Carrillo \& González de Mejía); however, higher nutritional quality has been found for amaranth leave proteins (Edelman \& Colt, 2016). Despite amaranth biomass is used preferably for animals feeding, it has been reported as an excellent source of antioxidant compounds for human benefits (Arce-Vazquez, Delgado-Fornué, Esquivel-Rosales \& Soriano-Santos, 2014). In some worldwide regions, amaranth leaves are edible and culturally accepted as a food ingredient in dishes such as soups and salads, and the consumers have described its taste as subtle and agreeable (Das, 2016). Moreover, amaranth plants are simple to grow and have a low environmental impact, making them a promising and sustainable protein source (Burlingame \& Dernini, 2012). Herein, it is analyzed the effect of processing protein concentrates from amaranth biomass on some structural features and functionality for food applications.

\section{Material and Methods}

\subsection{Material}

Amaranth biomass was harvested from organic amaranth crop (Amaranthus hypochondriacus) cultivated by "Tierra de Amaranto" organization in Queretaro, Mexico. Analytical grade reagents such as sodium chloride $(\mathrm{NaCl})$, hydrochloric acid, $(\mathrm{HCl})$ sodium hydroxide $(\mathrm{NaOH})$, dipotassium phosphate $\left(\mathrm{K}_{2} \mathrm{PO}_{4}\right)$ and monopotassium phosphate $\left(\mathrm{KH}_{2} \mathrm{PO}_{4}\right)$ were purchased from Sigma-Aldrich (Saint Louis, Missouri, USA), and virgin olive oil was bought in a local supermarket.

\subsection{Biomass Composition}

The dry matter (method 925.09), protein (method 954.01), ash (method 923.03), crude fat (method 920.39) and crude fiber (method 962.09) content of leaf biomass were determined as described in AOAC methods (AOAC, 1997). The total nitrogen-free extract (NFE) was calculated by difference [100 - (moisture+crude protein + crude fat + crude fiber + ash)] (Olvera-Novoa, Martinez Palacios, \& Real de Leon, 1994).

\subsection{Preparation of Protein Concentrates}

Amaranth biomass (sticks and leaves) was frozen at $-20{ }^{\circ} \mathrm{C}$ and mixed with deionized water $\left(500 \mathrm{mg} \mathrm{mL}^{-1}\right)$ at room temperature $\left(25^{\circ} \mathrm{C}\right)$ and blended followed by extrusion ( twin screw extruder 2" W/Packer S.S, Bonnot). Protein precipitation was carried out by a) isoelectric point acidification at $\mathrm{pH} 3.5$ (AP) and b) thermally treated at $90{ }^{\circ} \mathrm{C}$ for $10 \mathrm{~min}$ (TT) followed by centrifugation (20000 g for $20 \mathrm{~min}$ at $4{ }^{\circ} \mathrm{C}$ ). Recovered proteins were dried using oven vacuum drying (OVD), freeze-drying (FD) and spray-drying (SD). The working conditions were: OVD, $65^{\circ} \mathrm{C}$ until constant weight, freeze dryer (LABCONCO), and a co-current spray dryer (GEA Niro) at inlet and outlet temperatures of $160{ }^{\circ} \mathrm{C}$ and $95^{\circ} \mathrm{C}$, respectively (flow rate feed of $165 \mathrm{~mL} \mathrm{~min}^{-1}$ ).

\subsection{Gel-electrophoresis (SDS PAGE)}

Qualitative protein analysis took place by Sodium Dodecyl Sulfate-Polyacrylamide Gel Electrophoresis (SDS-PAGE) under reducing conditions using a Mini-Protean II dual cell system (Bio-Rad Laboratories). Protein was dispersed in a Laemmli sample buffer (Bio-Rad, Laboratories) $\left(4 \mathrm{mg} \mathrm{mL}^{-1}\right)$ and boiled for $2 \mathrm{~min}$ at $95{ }^{\circ} \mathrm{C}$. The electrophoresis gels were prepared using stacking and separating acrylamide solutions at $4.5 \%$ and $12.5 \%$ respectively. A Precision Plus Protein Dual Xtra Prestained Biorad (2 - $250 \mathrm{kDa})$ was used as a standard. For gels 
staining and destaining, solutions of Coomassie brilliant blue G-205 and a mixed of acetic acid and methanol (1:5) were used

\subsection{Isoelectric Point}

The apparent isoelectric point was determined using zeta potential measurements of protein solutions $\left(5 \mathrm{mg} \mathrm{mL}^{-1}\right)$ at room temperature $\left(25^{\circ} \mathrm{C}\right)$ as a function of $\mathrm{pH}(2.0,3.4,4.2,5.8,6.5$, and 6.7) using ZetaSizer Nano equipment (ZEN3600, Malvern Instruments Ltd.).

\subsection{Fourier Transform Infrared Spectrophotometry (FTIR)}

Protein footprint was observed by FTIR technique. The FTIR measurements of protein concentrates (powder) were recorded in the region of 400-4000 $\mathrm{cm}^{-1}$ with an Agilent Cary 630 spectrophotometer coupled with ATR ZNSe. The absorbance spectrums were analyzed using Microlab PC software (Agilent Technologies Inc., Santa Clara, CA, USA).

\subsection{Thermal Stability}

Differential Scanning Calorimetry (DSC) curves were obtained from a Q200 calorimeter (TA Instruments). The protein samples $(15 \mathrm{mg})$ sealed in a hermetic aluminum pan were heated from 20 to $140{ }^{\circ} \mathrm{C}$ using a heating rate of $2{ }^{\circ} \mathrm{C} \mathrm{min}^{-1}$. Enthalpy values were calculated using, Universal Analysis 2000 software (TA Instruments, US).

\subsection{Protein Solubility}

The solubility of the obtained dried proteins was determined according to the method described by Aluko and Yada (1997) with some modifications. Protein dispersions $\left(1 \mathrm{mg} \mathrm{mL}^{-1}\right)$ were prepared by dissolving protein powder in $0.1 \mathrm{M} \mathrm{NaOH}$ solution (control) adjusted at different $\mathrm{pH}$ values $(3,4,5,7$ and 9 ) using $0.1 \mathrm{M} \mathrm{HCl}$ solution. All samples were heated in a microplate water bath at $80{ }^{\circ} \mathrm{C}$ for $20 \mathrm{~min}$ and centrifuged at $20000 \mathrm{~g}$ for $20 \mathrm{~min}$ at room temperature $\left(25^{\circ} \mathrm{C}\right)$. The protein content in the supernatant was analyzed using the Total Protein Kit, Micro Lowry, Peterson's Modification (Sigma-Aldrich, US).

\subsection{Rheological Measurements}

For small deformation measurements, the protein solutions $\left(30 \mathrm{mg} \mathrm{mL}^{-1}\right)$ were heated in a water bath at $80{ }^{\circ} \mathrm{C}$ for one hour. Afterward, the samples were placed on a Peltier plate and cooled down to $25^{\circ} \mathrm{C}$ at a $10{ }^{\circ} \mathrm{C} \min ^{-1}$ rate. Oscillatory rheological measurements were performed using a stress-controlled rheometer $\left(\mathrm{DHR}_{1}\right)$ with a cone-plate $\left(40 \mathrm{~mm} 0.4969^{\circ}\right)$ geometry (Peltier-plate steel) (TA Instruments). Viscoelastic properties were measured as a function of frequency into the linear viscoelastic region (defined by an amplitude sweep test at $6.28 \mathrm{rad} \mathrm{s}^{-1}$ ). The effect of $\mathrm{pH}$, ionic strength, was also studied using a phosphate buffer ( $\mathrm{pH} 7$ and 9) and $2 \mathrm{M}$ $\mathrm{NaCl}$. Data analysis was done using Trios 3.2.0. 3877 software, DHR (TA Instruments, US). For mechanical properties of emulsions, the effect of oscillation amplitude (0.02-200\% strain), frequency sweep (200-0.02 rad $\left.\mathrm{s}^{-1}\right)$ and shear rate $\left(0.2-5001 \mathrm{~s}^{-1}\right)$ were analyzed.

\subsection{Emulsions Properties and Microstructure}

The emulsifying capacity (EC) was measured on emulsions formed by a mixture of an equal volume of protein dispersions (10 mg mL ${ }^{-1}$ protein) and virgin olive oil. Dispersions were homogenized in a homogenizer (T 18 Digital Ultra Turrax, IKA) at 15,000 rpm for 2 min. Both the capacity and stability of the emulsions (ES) after centrifugation and thermal treatment were determined by Equation 1.

$$
\text { EC }(\%)=[\text { height of emulsified layer }(\mathrm{cm}) / \text { total height }(\mathrm{cm})] \times 100
$$

The microstructure of protein emulsions (1\% true protein) was visualized in an inverted microscope Eclipse Ti-E (Nikon Instruments INC, USA) fitted with a camera (DU-885K-CS0, Andor) at $60 \mathrm{x}$ optical magnification. Images were recorded using an imaging analysis software Advanced Research (NIS-Elements, Nikon).

\subsection{Nutritional Quality of Protein}

Protein amino acids profile was carried out according to the method described by Alaiz, Navarro, Girón and Vioque (1992). Protein samples were hydrolyzed using $\mathrm{HCl}$ solution $(6 \mathrm{M})$ at $110{ }^{\circ} \mathrm{C}$ for 24 hours in sealed vials with nitrogen. After the acid solution evaporation in a vacuum oven at $65^{\circ} \mathrm{C}$, samples were dissolved in sodium borate $(1 \mathrm{M}, \mathrm{pH} 9)$. An excess of diethyl ethoxymethylenemalonate was added and heated $\left(50{ }^{\circ} \mathrm{C}\right)$ during 50 minutes for amino acids derivatization. Amino acids were separated using HPLC with spectrophotometric UV detection at $280 \mathrm{~nm}$ and a reversed-phase column (300 x $3.9 \mathrm{~mm}$, Nova-Pack C18, $4 \mu \mathrm{m}$; Waters) using a mixture of sodium of acetate ( $25 \mathrm{mM}, \mathrm{pH}$ 6) and acetonitrile (91:9) at a flow rate of $0.9 \mathrm{~mL} \mathrm{m^{-1 }}\left(18{ }^{\circ} \mathrm{C} \mathrm{x} 40 \mathrm{~min}\right)$. Tryptophan was determined by following the procedure described by Yust et al. (2004); protein samples were hydrolyzed using $\mathrm{NaOH}(4 \mathrm{M})$ at $0.9 \mathrm{~mL} \mathrm{~min}^{-1}$ at $18{ }^{\circ} \mathrm{C}$ during 8 minutes using the same chromatographic 
conditions. The reference pattern of amino acid required used to compare the essential amino acids (EAA) was for 2-5 years old children (FAO, 2011). The ratio of essential amino acids (EAA) and the total of amino acids (TAA) in protein concentrates were determined as (Equation 2).

$$
\mathrm{E} / \mathrm{T}(\%)=\mathrm{EAA} / \mathrm{TAA} * 100
$$

\section{Statistical Analysis}

The results were analyzed with one-way ANOVA, and the means were compared by the Tukey test $(\mathrm{p}<0.05)$ using statistical software Stat graphics Centurion XVI.I. Version 16.1.17.

\section{Results and Discussion}

\subsection{Composition of Amaranth Biomass Protein}

Proximate composition of amaranth leaves is shown in Table 1. Protein content reached $253 \mathrm{mg} \mathrm{g}^{-1}$ on a dry basis, which was similar to Amaranthus hybridus leaves $\left(\sim 228 \mathrm{mg} \mathrm{g}^{-1}\right)$ and higher than other starting materials reported for green leaves protein (Ngugi et al., 2017; Martin, Castellani, de Jong, Bovetto \& Schmitt, 2018).

Table 1. Proximal composition of Amaranth hypochondriacus biomass

\begin{tabular}{ll}
\hline Chemical composition & $\mathrm{mg} \mathrm{g}^{-1}$ of sample \\
\hline Dry matter & $816 \pm 1.47$ \\
Ash & $266 \pm 0.12$ \\
Protein $(\mathrm{N} \mathrm{x} \mathrm{6.25)}$ & $253 \pm 0.26$ \\
Crude fat & $21 \pm 0.04$ \\
Crude fiber & $77 \pm 0.19$ \\
NFE & $381 \pm 0.25$ \\
\hline
\end{tabular}

Standard deviations $(\mathrm{n}=3)$.

Protein extractability significantly enhanced by mechanical processing using extrusion compared to blending (88.5 $\mathrm{mg} \mathrm{g}^{-1}$ and $27.3 \mathrm{mg} \mathrm{g}^{-1}$ respectively). Unlike blending exerts a shear force, extrusion combines radial compression and shearing that probably caused a higher disruption of the biomass cells increasing the release of protein.

\subsection{Structural Characterization}

The apparent isoelectric point (IEP) of amaranth biomass protein resulted in around 3.5, which is smaller than the values reported for other protein green leave sources $(4,5)$, probably due to its intrinsic characteristics such as amino acid profile and crop cultivation conditions (Barbeau \& Kinsella, 1988; Douillard \& De Mathan, 1994).

The presence of soluble proteins in amaranth biomass was confirmed by gel electrophoresis (Figure 1C). It was observed that the major soluble protein was the white fraction, denoted by high-intensity bands at $\sim 55 \mathrm{kDa}$ and $\sim 12.5 \mathrm{kDa}$, which constitute the large (L) and small (S) subunits of RuBisCO protein. However, another low molecular weight bands, probably from thylakoid and chlorophyll-related proteins (green fraction) were also found (Wildman \& Bonner, 1947).

Structural differences between the acidic precipitated (AP), thermally treated (TT) proteins analyzed by reflectance-absorbance (FT-IR), and calorimetric measurements are shown in Figure 1 (A and B respectively). In both analyses, TP demonstrated loss of structural elements of the protein, shown by a decrease in absorbance intensity peaks of protein backbone represented mainly by amides A, I, II, and III. Calorimetric results (DSC) of $\mathrm{AP}$ and TP protein samples exhibited enthalpic peaks during heating, which is considered associated with native protein content (Martin, Nieuwland \& de Jong, 2014). Nonetheless, a peak shift in the thermogram was observed for TP protein, suggesting a loss of protein structure in comparison to those obtained by acidic precipitation. 


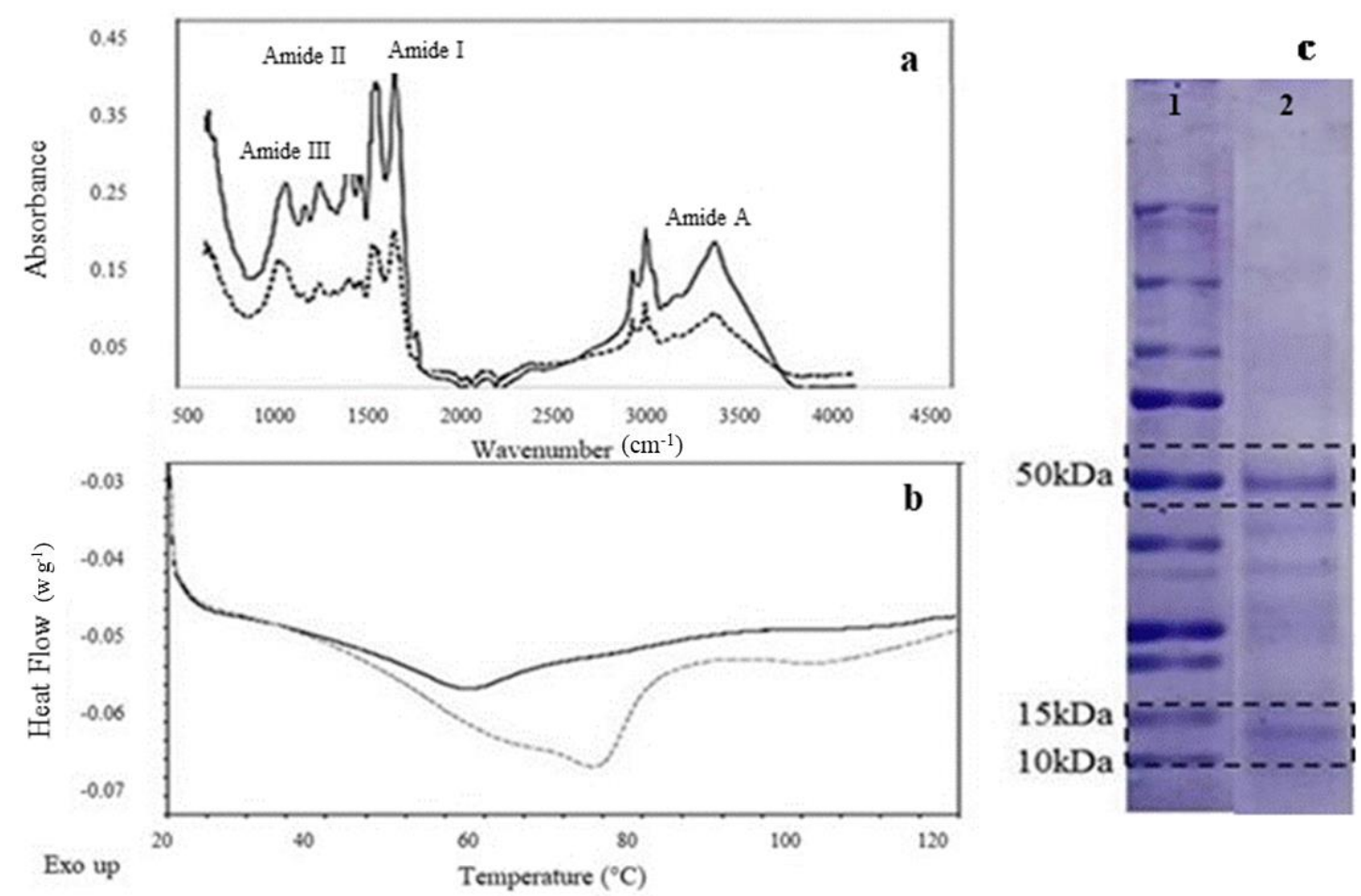

Figure 1. FT-IR (a) and DSC (b) data for acid (continuous line) and thermally (dashed line) precipitated. SDS-PAGE analysis of total soluble proteins from amaranth biomass (c)

It is widely accepted that processing conditions may affect the thermal transition of the proteins; this fact could partly explain the differences found in our study in comparison to those previously reported. The differences in thermal stability may arise from extrinsic factors such as high-temperature exposition (during drying and thermal precipitation) and the ionic strength of the extraction solution. These characteristics may lead to a partial disruption of the protein, causing changes in thermal stability. The denaturation temperature of protein from amaranth biomass $\left(57.7^{\circ} \mathrm{C}\right.$ ) has not been previously reported. Anyhow, these values are lower than those reported for alfalfa and spinach RuBisCO protein $\left(66.5^{\circ} \mathrm{C}\right.$ and $64.9^{\circ} \mathrm{C}$ respectively) (Martin et al., 2014). In this study, protein purification was no applied; thus, considering the product as total soluble proteins, are expected some differences on structural characteristics. After these first approaches (structural features and yield), it was established to investigate the effect of drying processing exclusively on mechanically extruded, and acid precipitated biomass soluble proteins.

\subsection{Effect of Drying on Protein Features}

Protein precipitates from amaranth biomass dried by vacuum-oven drying (VOD), spray drying (SD) and freeze-drying (FD) methods showed a total protein content of $461 \mathrm{mg} \mathrm{g}^{-1} \mathrm{wt} \%, 422 \mathrm{wt} \mathrm{mg} \mathrm{g}{ }^{-1}$, and $514 \mathrm{mg} \mathrm{g}^{-1}$ respectively, showing no significant differences $(\mathrm{p}>0.05)$. These results were higher than amaranth leaf concentrates (A. hybridus) obtained by coagulation (364 mg g $\mathrm{m}^{-1}$ ) (Ngugi et al., 2017). Additionally, a proof dialysis step was included increasing the purity of protein to 76 wt \% (VOD), also higher than $A$. hypochondriacus leaf $\left(65 \mathrm{mg} \mathrm{g}^{-1}\right)$ and alfalfa $\left(60 \mathrm{mg} \mathrm{g}^{-1}\right)$ protein isoelectric precipitated using purification system and dialysis respectively (Ghaly \& Alkoaik, 2010; Hojilla - Evangelista, Selling, Hatfield \& Digman, 2017). However, to simplify the separation method and avoid the processing cost, this step (purification) was not considered in this study.

\subsubsection{Solubility}

In general, the sort of processing influenced the protein solubility; it was observed an improvement in the solubility by an increment of solvent alkalinity (Figure 2). Vacuum dried proteins obtained by AP showed higher solubility $(60 \%)$ when compared to TP proteins $(40 \%)$ for the entire $\mathrm{pH}$ range evaluated (3-9). These results might be correlated with previously reported structural changes observed in protein concentrates thermally treated (TT). 


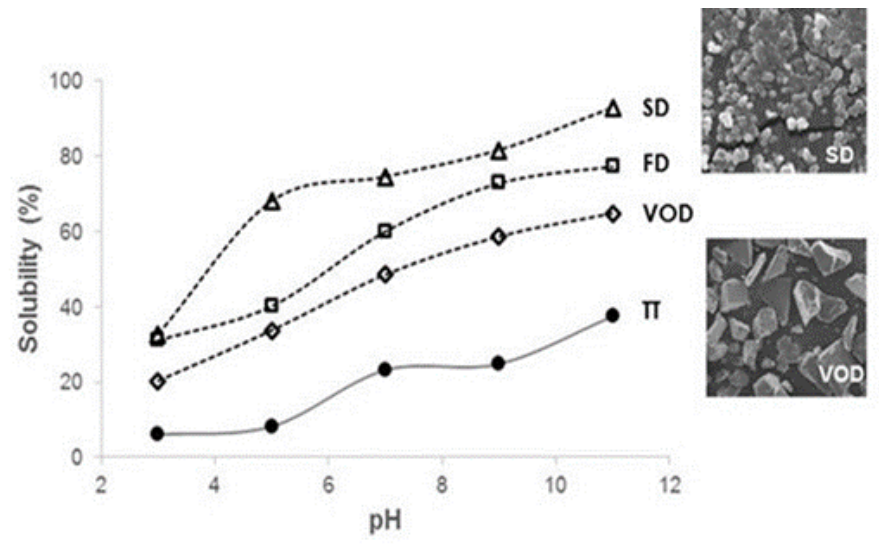

Figure 2. Solubility curve of amaranth biomass protein thermally treated (TT) and acid precipitated subjected to vacuum oven drying (VOD), freeze-drying (FD) and spray drying (SD)

For AP proteins, the SD drying showed the best solubility, followed by FD and VOD with maximum values of around $90 \%, 70 \%$, and $60 \%$ respectively. There were no found solubility reports for amaranth leaf proteins, but it is worth noting that similar solubility values $(\sim 90 \%)$ for white fraction protein obtained from alfalfa and sugar beet leaves were achieved (Lamsal, Koegel \& Gunasekaran, 2007; Tenorio et al., 2017). Solubility plays an important role to define the use of the protein as a food ingredient. Because this characteristic determines other interactions, which in turn can affect several functional properties such as emulsification, foaming, and oil/water absorption.

\subsubsection{Rheological Properties}

Based on solubility results, rheological behavior was evaluated uniquely on protein concentrates dried by spraying and lyophilization. Small deformation measurements for pre-heated protein dispersions (SD and FD) showed, in general, a viscoelastic solid-like behavior $\left(G^{\prime}>G^{\prime \prime}\right)$. However, SD protein dispersions had a more rigid structure denoted by higher $\mathrm{G}^{\prime}$ than FD protein (Figure 3).
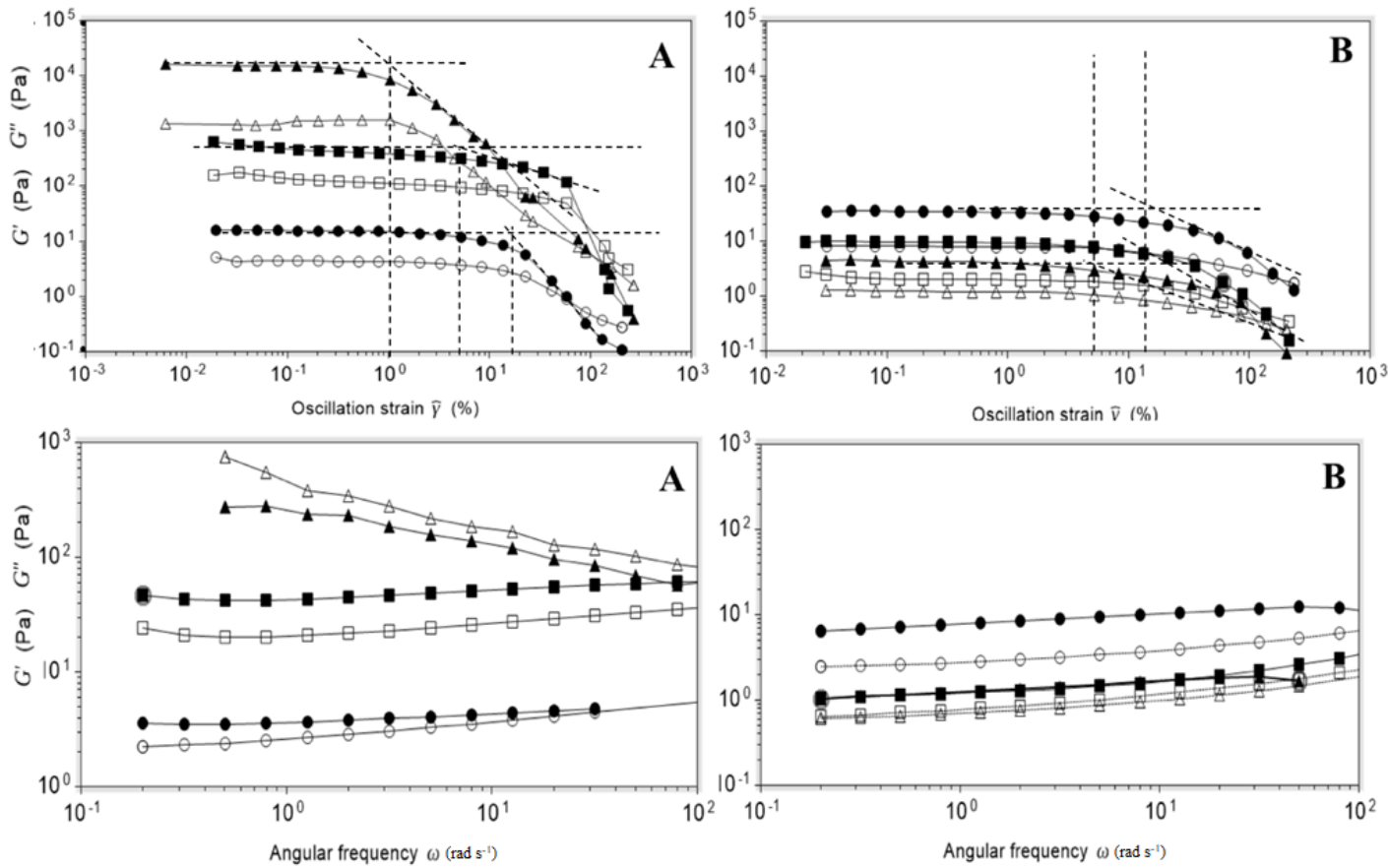

Figure 3. Amplitude and frequency viscoelastic response of SD (A) and FD (B) protein solutions at different extrinsic factors: $\mathrm{pH} 7$ (circles), $\mathrm{pH} 9$ (triangles), $\mathrm{NaCl}$ (square) 
The rheological response of SD as a function of frequency confirmed a strong association of protein molecules $\left(G^{\prime}>G^{\prime \prime}\right)$, as opposed to FD in which there was no frequency dependence (weak interactions). Even though there are not rheological data for amaranth leaf protein and few for green leave proteins, the results presented here were similar to blue-green algae protein (Chronakis, 2001), where an elastic modulus of 2 decades for was reached. In comparison to the most studied proteins such as soy and whey protein isolates, lower $\mathrm{G}^{\prime}$ values are reported (1 Pa and $10 \mathrm{~Pa}$ respectively) at both $4 \%$ and $10 \%$ protein concentrations. Rheological differences observed between samples can be attributed to higher interactions in SD (water and protein chains), which might contribute to the formation of a more stable protein aggregates network.

Higher storage modulus $\left(\mathrm{G}^{\prime}\right)$ by increasing the alkalinity $(\mathrm{pH}$ 9) was observed, probably this fact caused better solubilization of proteins enhanced the entanglement of proteins. Raising the ionic strength in the systems caused both, $\mathrm{G}^{\prime}$ drop and a critical strain detriment $(\sim 1 \%)$ compared to control systems $(\sim 10 \%)$. These data are consistent with previous results in alfalfa protein (Libouga, Aguié-Béghin \& Douillard, 1996), where a negative rheological effect occurred. Probably an excess of electrostatic interactions caused by the $\mathrm{NaCl}$ addition, disturbed the protein interactions causing decreasing in solubility (salting-out) and therefore its precipitation (Curtis \& Lue, 2006).

\subsubsection{Emulsifying Properties}

Both FD and SD proteins emulsions after homogenization showed an emulsification activity (EA) above $95 \%$. Nevertheless, after gravity forces (centrifugation) and heat application, FD emulsions were more stables ( $63 \%$ and $79 \%$ ) than SD samples (23\% and $60 \%$ respectively). FD proteins could present greater interfacial hydrophobic interactions of proteins, favoring protein adsorption at the surface of the oil phase, which allows shielding the fat droplets of the system. From this point of view, this action might interfere in preventing the system destabilization by coalescence. Some authors have reported that during freeze-drying mechanism, the partially unfolded proteins cause an open structure and thus, higher hydrophobic groups are exposed (Ghribi et al., 2015; Hu et al., 2010; Tontul, Kasimoglu, Asik, Atbakan \& Topuz, 2018).

Protein emulsions rheology showed higher $G^{\prime}$ values and a larger distance between modulus $\left(G^{\prime}, G^{\prime \prime}\right)$ for FD emulsions in comparison to SD, suggesting that molecular forces are stronger and more stable. The images of the emulsions confirm those results; FD emulsions showed a uniform and smaller droplets than the ones formed by SD proteins (Figure 4).

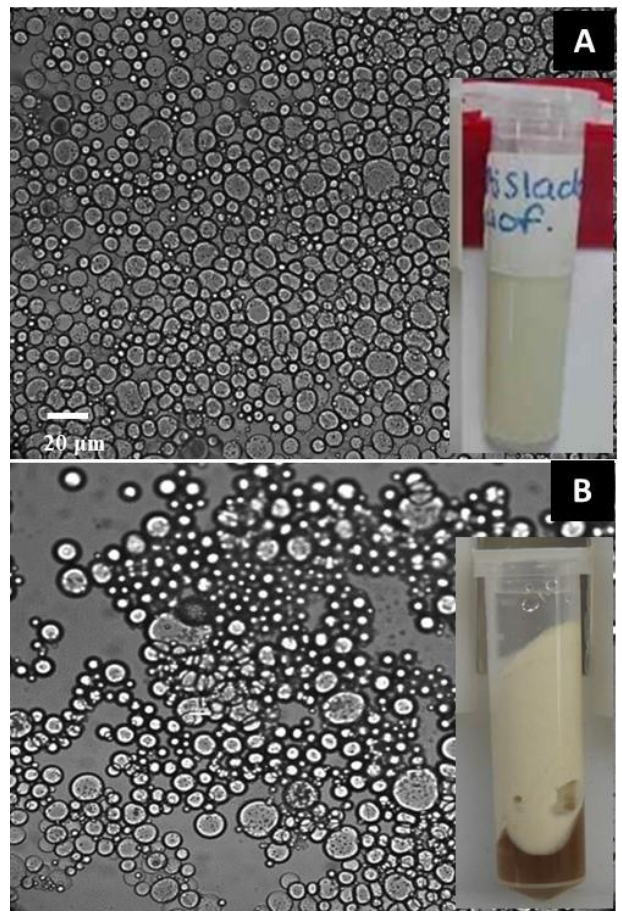

Figure 4. Emulsions micro images (60x) using freeze-dried (A) and spray dried (B) amaranth biomass protein 


\subsection{Nutritional Quality}

A comparison between the EAA \% and the E/T \% obtained from the amino acid profile in Amaranthus hypochondriacus soluble proteins (ASP), literature values (A. hybridus), (Ngugi et al., 2017) and FAO scoring patterns are shown in Table 2.

Table 2. Comparison of essential amino acids (EAA) content and the proportion of EAA in relation to the total amino acids (E/T ratio) in A. hypochondriacus, A.hybridus leaf protein and $\mathrm{FAO} / \mathrm{WHO}$ pattern requirements (mg $\mathrm{g}^{-1}$ protein)

\begin{tabular}{llll}
\hline Amino acids profile & $\begin{array}{l}\text { Leaf protein } \\
\text { (A.hypochondriacus) }\end{array}$ & $\begin{array}{l}\text { Leaf protein }^{\text {a }} \text { (A. hybridus) } \\
\text { Asp }\end{array}$ & $\begin{array}{l}\text { Preschool child } \\
\text { AA scoring pattern }\end{array}$ \\
\hline Asp & 53 & 48 & - \\
Glu & 102 & 54 & - \\
Ser & 29 & 7 & - \\
*His & $\mathbf{2 1}$ & 17 & 18 \\
Gly & 36 & 12 & - \\
*Thr & $\mathbf{3 4}$ & 11 & 27 \\
Arg & 110 & 25 & \\
Ala & 23 & 12 & \\
Pro & 26 & - & 46 \\
*AAA & $\mathbf{7 5 *}$ & 33 & 42 \\
*Val & $\mathbf{5 7}$ & 11 & 26 \\
*SAA & $\mathbf{2 6}$ & 50 & 31 \\
*Ile & $\mathbf{4 0}$ & 9 & 63 \\
*Leu & $\mathbf{6 9}$ & 21 & 52 \\
*Lys & $\mathbf{5 2}$ & 37 & 7.4 \\
*Trp & $\mathbf{1 2} *$ & 14 & 328 \\
EAA & $\mathbf{3 8 6}$ & 203 & 360 \\
E/T \% & $\mathbf{4 9 0}$ & - & \\
\hline
\end{tabular}

$\mathrm{AAA}=$ Aromatic Amino Acids (methionine + cysteine)

$\mathrm{SAA}=$ Sulfur Amino Acids (phenylalanine + tyrosine)

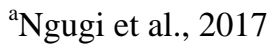

${ }^{\mathrm{b}}$ FAO amino acid scoring pattern (2011)

The EAA reached for ASP (38.6) was comparable to amino acids scoring pattern for the preschool children (32.8) and considerably higher than A. hybridus leaf proteins (20.3) and other leaf protein such as Medicago sativa and Asphodeline plant (Hojilla-Evangelista et al., 2017; Zengin et al., 2012). It is worth to underline, that the EAA scoring for ASP in this work meets the Codex Alimentarius requirements (Codex Alimentarius Commission, 2007), for using vegetable protein in food products. Specifically, it must contain at least $5.8 \%$ lysine (Lys), $2.5 \%$ SAA, and $1.1 \%$ Trp. Likewise, the percentage of E/T of ASP was much higher (49\%) than FAO recommendations $(36 \%)$.

\section{Conclusions}

The amaranth leaf biomass resulted in an excellent alternative for the production of a high-quality protein source for human consumption. The characteristics of the developed proteinaceous product are suitable as a functional ingredient for food applications. Spray-dried proteins are advisable for liquid and semi-liquid food systems, such as beverages and soups (highly soluble), and in the case of freeze-dried is recommended for emulsion-based products as salad dressings, dips or mayonnaise homologous with an extended storing stability. This product can serve as nutritional complement food products, which are naturally low in good quality protein content, and given the simplicity of processing and the biomass availability, it can be considered a low-cost ingredient for improving poor protein diets in developing countries.

\section{Acknowledgments}

This work was supported by the CONACYT under grant FOINS No. 24639; analytical equipment support by the CONACYTLAB under grant 2009-01-123913. We also would like to thanks, CIATEJ southeast unit for the infrastructure and Dr. Luis Chel and Dr. Mukthar Peraza for amino acid determinations (UADY). 


\section{References}

Alaiz, M., Navarro, J. L., Girón, J., \& Vioque, E. (1992). Amino acid analysis by high-performance liquid chromatography after derivatization with diethyl ethoxymethylenemalonate. Journal of Chromatography A, 591(1-2), 181-186. https://doi.org/10.1016/0021-9673 (92) 80236-N

Aluko, R. E., \& Yada, R. Y. (1997). Some physicochemical and functional properties of cowpea (Vigna unguiculata) isoelectric protein isolate as a function of $\mathrm{pH}$ and salt concentration. International Journal of Food Sciences and Nutrition, 48(1), 31-39. https://doi.org/10.3109/09637489709006961

AOAC (1997). Official Methods of Analysis, 17th ed., Association of Official Analytical Chemists, Washington, DC.

Arce-Vazquez, M. B., Delgado-Fornué, E., Esquivel-Rosales, M. E., \& Soriano-Santos, J. (2014). Amaranth (Amaranthus Hypochondriacus L.): Use of Lignocellulosic biomass to obtain antioxidant extracts through acid hydrolysis. Journal of Chemical, Biological and Physical Sciences, 4(5), 61-73.

Barbeau, W. E., \& Kinsella, J. E. (1988). Ribulose bisphosphate carboxylase/oxygenase (rubisco) from green leaves - potential as a food protein. Food Reviews International, 4(1), 93-127. https://doi.org/10.1080/87559128809540823

Burlingame, B., \& Dernini, S. (2012). Sustainable Diets and Biodiversity: Directions and Solutions for Policy, Research and Action. International Scientific Symposium, Biodiversity and Sustainable Diets United Against Hunger, FAO Headquarters, Rome, Italy, 3-5 November 2010. In Sustainable Diets and Biodiversity: Directions and Solutions for Policy, Research and Action. International Scientific Symposium, Biodiversity and Sustainable Diets United Against Hunger, FAO Headquarters, Rome, Italy, 3-5 November 2010. Food and Agriculture Organization of the United Nations (FAO).

Chronakis, I. S. (2001). Gelation of edible blue-green algae protein isolate (Spirulina platensis strain pacifica): thermal transitions, rheological properties, and molecular forces involved. Journal of Agricultural and Food Chemistry, 49(2), 888-898. https://doi.org/10.1021/jf0005059

Codex Alimentarius Commission (2007), Codex General guidelines for the utilization of vegetable protein products (VPP) in foods (CAC/GL 4-1989). In Cereals, pulses, legumes and vegetable proteins, Food and Agriculture Organization of the United Nations, Rome, pp. 174.

Consultation, FAO Expert (2011). Dietary protein quality evaluation in human nutrition. FAO Food Nutr., 92, $1-66$.

Curtis, R. A., \& Lue, L. (2006). A molecular approach to bioseparations: protein-protein and protein-salt interactions. Chemical Engineering Science, 61(3), 907-923. https://doi.org/10.1016/j.ces.2005.04.007

Das, S. (2016). Future Prospects in Amaranth Research. In: Amaranthus: A Promising Crop of Future (pp. 167-172). Springer, Singapore. https://doi.org/10.1007/978-981-10-1469-7_11

De Jong, G. A. H., Geerdink, P., Bussmann, P. J. T., \& Hylkema, N. (2015). U.S. Patent Application No. $14 / 654,947$.

Douillard, R., \& De Mathan, O. (1994). Leaf protein for food use: potential of rubisco. In New and developing sources of food proteins (pp. 307-342). Springer, Boston, MA. https://doi.org/10.1007/978-1-4615-2652-0_10

Edelman, M., \& Colt, M. (2016). Nutrient Value of Leaf vs. Seed. Frontiers in Chemistry, 4, 32. https://doi.org/10.3389/fchem.2016.00032

Fiorda, F. A., Soares Júnior, M. S., da Silva, F. A., Souto, L. R. F., \& Grosmann, M. V. E. (2013). Amaranth flour, cassava starch and cassava bagasse in the production of gluten - free pasta: technological and sensory aspects. International Journal of Food Science \& Technology, 48(9), 1977-1984. https://doi.org/10.1111/ijfs.12179

Ghaly, A. E., \& Alkoaik, F. N. (2010). Extraction of protein from common plant leaves for use as human food. American Journal of Applied Sciences, 7(3), 331. https://doi.org/10.3844/ajassp.2010.331.342

Ghribi, A. M., Gafsi, I. M., Blecker, C., Danthine, S., Attia, H., \& Besbes, S. (2015). Effect of drying methods on physico-chemical and functional properties of chickpea protein concentrates. Journal of Food Engineering, 165, 179-188. https://doi.org/10.1016/j.jfoodeng.2015.06.021

Hojilla-Evangelista, M. P., Selling, G. W., Hatfield, R., \& Digman, M. (2017). Extraction, composition, and 
functional properties of dried alfalfa (Medicago sativa L.) leaf protein. Journal of the Science of Food and Agriculture, 97(3), 882-888. https://doi.org/10.1002/jsfa.7810

Hu, X. Z., Cheng, Y. Q., Fan, J. F., Lu, Z. H., Yamaki, K., \& Li, L. T. (2010). Effects of drying method on physicochemical and functional properties of soy protein isolates. Journal of Food Processing and Preservation, 34(3), 520-540. https://doi.org/10.1111/j.1745-4549.2008.00357

Lamsal, B. P., Koegel, R. G., \& Gunasekaran, S. (2007). Some physicochemical and functional properties of alfalfa soluble leaf proteins. LWT-Food Science and Technology, 40(9), 1520-1526. https://doi.org/10.1016/j.lwt.2006.11.010

Libouga, D. G., Aguié-Béghin, V., \& Douillard, R. (1996). Thermal denaturation and gelation of rubisco: effects of $\mathrm{pH}$ and ions. International Journal of Biological Macromolecules, 19(4), 271-277. https://doi.org/10.1016/S0141-8130 (96)01137-3

Martin, A. H., Castellani, O., de Jong, G. A., Bovetto, L., \& Schmitt, C. (2018). Comparison of the functional properties of RuBisCO protein isolate extracted from sugar beet leaves with commercial whey protein and soy protein isolates. Journal of the Science of Food and Agriculture, 99(4), 1568-1576. https://doi.org/10.1002/jsfa.9335

Martin, A. H., Nieuwland, M., \& de Jong, G. A. (2014). Characterization of heat-set gels from RuBisCO in comparison to those from other proteins. Journal of Agricultural and Food Chemistry, 62(44), 10783-10791. https://doi.org/10.1021/jf502905g

Montoya-Rodríguez, A., Gómez-Favela, M. A., Reyes-Moreno, C., Milán-Carrillo, J., \& González de Mejía, E. (2015). Identification of bioactive peptide sequences from amaranth (Amaranthus hypochondriacus) seed proteins and their potential role in the prevention of chronic diseases. Comprehensive Reviews in Food Science and Food Safety, 14(2), 139-158. https://doi.org/10.1111/1541-4337.12125

Ngugi, C. C., Oyoo-Okoth, E., Manyala, J. O., Fitzsimmons, K., \& Kimotho, A. (2017). Characterization of the nutritional quality of amaranth leaf protein concentrates and suitability of fishmeal replacement in Nile tilapia feeds. Aquaculture Reports, 5, 62-69. https://doi.org/10.1016/j.aqrep.2017.01.003

Olvera-Novoa, M. A., Martinez Palacios, C. A., \& Real de Leon, E. (1994). Nutrition of fish and crustaceans: a laboratory manual. Food and Agriculture Organization of The United Nations-FAO. Retrieved from http://www.fao.org/3/ab479e/AB479E00.htm

Phillips, L.G., Whitehead, D. M., \& Kinsella, J. (Ed.) (1994). In Structure-function properties of food proteins (pp. 3-17). Academic Press, Inc., United States of America (US).

Rastogi, A., \& Shukla, S. (2013). Amaranth: a new millennium crop of nutraceutical values. Critical Reviews in Food Science and Nutrition, 53(2), 109-125. https://doi.org/10.1080/10408398.2010.517876

Shen, L., Wang, X., Wang, Z., Wu, Y., \& Chen, J. (2008). Studies on tea protein extraction using alkaline and enzyme methods. Food Chemistry, 107(2), 929-938. https://doi.org/10.1016/j.foodchem.2007.08.047

Tenorio, A. T., Schreuders, F. K. G., Zisopoulos, F. K., Boom, R. M., \& Van der Goot, A. J. (2017). Processing concepts for the use of green leaves as raw materials for the food industry. Journal of Cleaner Production, 164, 736-748. https://doi.org/10.1016/j.jclepro.2017.06.248

Tontul, İ., Kasimoglu, Z., Asik, S., Atbakan, T., \& Topuz, A. (2018). Functional properties of chickpea protein isolates dried by refractance window drying. International Journal of Biological Macromolecules, 109, 1253-1259. https://doi.org/10.1016/j.ijbiomac.2017.11.135

Van der Spiegel, M., Noordam, M. Y., \& Van der Fels - Klerx, H. J. (2013). Safety of novel protein sources (insects, microalgae, seaweed, duckweed, and rapeseed) and legislative aspects for their application in food and feed production. Comprehensive Reviews in Food Science and Food Safety, 12(6), 662-678. https://doi.org/10.1111/1541-4337.12032

Wildman, S. G., \& Bonner, J. (1947). The proteins of green leaves. 1. Isolation, enzymatic properties and auxin content of spinach cytoplasmic proteins", Archives of Biochemistry, 14, 381-413.

Yust, M. M., Pedroche, J., Girón-Calle, J., Vioque, J., Millán, F., \& Alaiz, M. (2004). Determination of tryptophan by high-performance liquid chromatography of alkaline hydrolysates with spectrophotometric detection. Food Chemistry, 85(2), 317-320. https://doi.org/10.1016/j.foodchem.2003.07.026

Zengin, G., Aktumsek, A., Guler, G. O., Cakmak, Y. S., Girón-Calle, J., Alaiz, M., \& Vioque, J. (2012). Nutritional quality of protein in the leaves of eleven Asphodeline species (Liliaceae) from Turkey. Food 
Chemistry, 135(3), 1360-1364. https://doi.org/10.1016/j.foodchem.2012.05.084

\section{Appendix A}

\section{Protein concentrates processing}

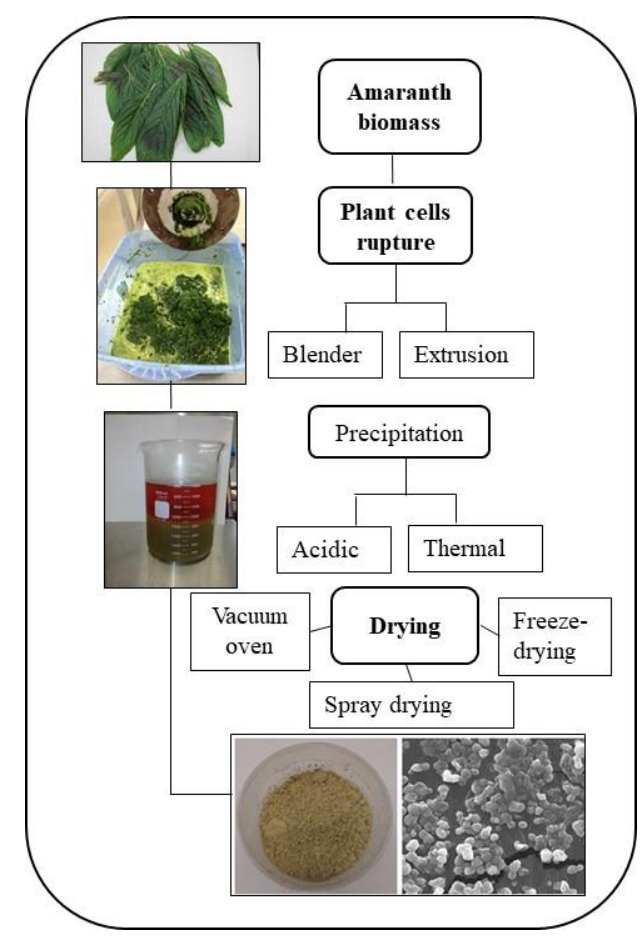

Figure A. Protein concentrates processing

\section{Copyrights}

Copyright for this article is retained by the author(s), with first publication rights granted to the journal.

This is an open-access article distributed under the terms and conditions of the Creative Commons Attribution license (http://creativecommons.org/licenses/by/4.0/). 